Polish Journal of Microbiology

2016, Vol. 65, No 3, 307-318

ORIGINAL PAPER

\title{
Prevalence of Biofilm Formation and Wide Distribution of Virulence Associated Genes among Vibrio spp. Strains Isolated from the Monastir Lagoon, Tunisia
}

\author{
BADREDDINE MECHRI ${ }^{1,2 *}$, AMEL MEDHIOUB ${ }^{2}$, MOHAMED NEJIB MEDHIOUB $^{2}$ \\ and MAHJOUB AOUNI ${ }^{1}$ \\ ${ }^{1}$ Laboratory of Contagious Diseases and Biologically Active Substances, Faculty of Pharmacy, \\ University of Monastir, Monastir, Tunisia \\ ${ }^{2}$ Laboratory of Aquaculture, National Institute of Marine Sciences and Technology, Monastir, Tunisia
}

Submitted 15 October 2014, revised 25 May 2015, accepted 11 February 2016

Abstract

In the current study, 65 Vibrio spp. were isolated from the Monastir lagoon water, were characterized phenotypically and genotypically. In addition, we looked for the presence of three Vibrio parahaemolyticus virulence genes (th, trh and $t d h$ ) and ten Vibrio cholerae virulence genes $(c t x \mathrm{~A}, v p i, z o t, a c e, t o x \mathrm{R}, \operatorname{tox} \mathrm{T}, t o s \mathrm{~S}, t o x \mathrm{RS}, t c p \mathrm{~A}$ and $c p \mathrm{P})$. We also investigated the antibiotic susceptibilities and the adherence ability of the identified strains to abiotic material and to biotic surfaces. The cytotoxicity activity against HeLa and Vero cell lines were also carried out for all tested strains. All Vibrio isolates were identified to the species level and produced several hydrolytic exoenzymes. The results also revealed that all strains were expressing high rates of resistance to tested antibiotics. The minimum inhibitory concentration (MIC) values showed that tetracycline and chloramphenicol were the most effective antibiotics against the tested bacteria. Vibrio alginolyticus and $V$. cholerae species were the most adhesive strains to both biotic and abiotic surfaces. Besides, V.alginolyticus isolates has the high levels of recombination of genes encoding V.cholerae and V.parahaemolyticus virulence factors. In vitro cytotoxic activities of several Vibrio extracellular product were also observed among HeLa and Vero cells.

Ke y words: Vibrio spp., antibiotic susceptibility, biofilm, Monastir lagoon, virulence genes

\section{Introduction}

Vibrio species are widely distributed in marine environments, estuarine waters, sediments and hatcheries microbiota (Costa et al., 2010; Mechri et al., 2012). They have been associated with some human infections (Barton and Acton, 2009; Reilly et al., 2011) and can cause several epizootics in many aquatic animals, especially in fish, shellfish and crustaceans (Ben KahlaNakbi et al., 2006; Rebouças etal., 2011).

The basis of pathogenicity of Vibrio parahaemolyticus depends on three major virulence factors having several biological activities, the thermostable direct haemolysin $(t d h)$; the TDH-related haemolysin (trh); and the thermolabile haemolysin (tlh) (Matsumoto et al., 2000; Nair and Hormazabal, 2005). Vibrio cholerae carries a wealth of pathogenic determinants encoded by two separate genetic elements; the cholera toxin genes encoded by the filamentous phage, $C T X \varphi$ and the putative prophage $V P I \varphi$, which encodes several genes clusters required for toxin co-regulated pilus (TCP) production, accessory colonization factors (ACF) and the tox $\mathrm{T}, t c p \mathrm{P}, t c p \mathrm{H}$ and $t c p$ I regulatory proteins (Peterson, 2002). Other factors have been associated with enteropathogenicity including two membrane regulatory proteins (tox $\mathrm{R}$ and toxS) (Miller et al., 1987; Miller et al., 1989), a zonula occludens toxin (zot) (Fasano et al., 1991) and an accessory cholera enterotoxin (ace) (Trucksis et al., 1993).

In most ecosystems, bacterial communities often adopt a sessile biofilm lifestyle in the target to increase their surviving chances by protecting themselves from adverse environmental stressful conditions (HallStoodley etal., 2004; Hoffman et al., 2005). Biofilms exhibits complex spatial organization composed by capillary water channels allowing the flow of nutrients and oxygen into the interior of the biofilm-associated bacteria and allow toxic metabolites to diffuse out of the biofilm (Costerton et al., 1995).

The present study was aimed for isolation and identification of three Vibrio species (Vibrio alginolyticus, $V$.cholerae and V.paraheamolyticus) from the Monastir lagoon water, for detection of biofilm formation and

\footnotetext{
* Corresponding author: B. Mechri, Faculté de Pharmacie, Monastir, Tunisie; e-mail: mechri_bader@yahoo.fr
} 
for investigation of the presence of three V.parahaemolyticus virulence genes (tlh, trh and $t d h$ ) and ten $V$. chole rae virulence genes (ctxA, vpi, zot, ace, tox $\mathrm{R}$, tox $\mathrm{T}$, tos $\mathrm{S}$, tox $\mathrm{RS}, t c p \mathrm{~A}$ and $t c p \mathrm{P}$ ). The isolates were also tested for their cytotoxic activity towards two epithelial cells. Their pattern of resistance to antibiotics was also carried out.

\section{Experimental}

\section{Materials and Methods}

Study area and sample collection. The lagoon of Monastir is situated on the eastern littoral of Tunisia, between the experimental fish and shellfish hatcheries of the National Institute of Marine Sciences and Technologies and a private hatchery of Sparus aurata and Dicentrarchus labrax. This part of the lagoon is used for supplying the fish and clam hatcheries with rearing water and also used for clam (Ruditapes decussatus) farming. The water samples were collected every ten days for a period of 12 months (January to December 2009). All the samples were collected in sterile glass containers $(500 \mathrm{ml})$ and transported in isothermal condition to the laboratory for analysis within $2 \mathrm{~h}$.

Isolation and bacterial characterization. Vibrio species were isolated using the membrane filtration technique. The water samples were filtrated through a sterile $0.45 \mu \mathrm{m}$ pore size cellulose nitrate membrane filter (Millipore, Germany). These filters were transferred in alkaline peptone water $(\mathrm{pH} 8.6,1 \% \mathrm{NaCl})$ and incubated at $37^{\circ} \mathrm{C}$ for $24 \mathrm{~h}$. The enrichments were streaked onto Thiosulfate Citrate Bile Salts Sucrose agar (TCBS agar) supplemented with $2 \% \mathrm{NaCl}$ to increase the detection of Vibrio species and incubated at $37^{\circ} \mathrm{C}$ for $24 \mathrm{~h}$.

Preliminary identification of the strains had been performed on the bases of colony morphology on TCBS (Scharlau Microbiology, Spain) supplemented with 2\% $\mathrm{NaCl}$, Gram nonstaining ( $\mathrm{KOH})$ method, cytochrome oxidase activity, motility (Mannitol-Motility agar; Pronadisa, Madrid, Spain), resistance to vibriostatic $\mathrm{O} 129(10$ and $150 \mu \mathrm{g})$, salt requirement (growth on $0 \%$, $2 \%, 4 \%, 8 \%$ and $10 \% \mathrm{NaCl}$ medium) and growth at 23 and $37^{\circ} \mathrm{C}$. All of the isolates were processed using API 20E strips (bioMerieux), following the manufacturer's instructions. Ability of Vibrio isolates to produce extracellular enzymes such as lipase, amylase, lecithinase, caseinase and Dnase was performed as described previously (Liu et al., 1996). Vibrio strains were assessed for hemolytic activity on blood base agar supplemented with $5 \%(\mathrm{v} / \mathrm{v})$ human blood. The strains were conserved as frozen stocks at $-80^{\circ} \mathrm{C}$ in tryptic soy broth (TSB; Bio-Rad, France) with $2 \% \mathrm{NaCl}$ plus $15 \%$ (v/v) glycerol.

Antibacterial susceptibility. Antibiotic susceptibility tests were performed using the disk diffusion method on Mueller-Hinton agar (bioMérieux, France) plates supplemented with $1 \% \mathrm{NaCl}$ as described by Ottaviani et al. (2001). The commercial disks (Bio-Rad, France) containing the following antibiotics were used: ampicillin $(10 \mu \mathrm{g})$, chloramphenicol $(30 \mu \mathrm{g})$, co-trimoxazole $(25 \mu \mathrm{g})$, gentamicin $(10 \mu \mathrm{g})$, nalidixic acid $(30 \mu \mathrm{g})$, streptomycin $(10 \mu \mathrm{g})$, tetracyclin $(30 \mu \mathrm{g})$, erythromycin $(15 \mu \mathrm{g})$, kanamycin $(30 \mu \mathrm{g})$ and carbenicillin $(100 \mu \mathrm{g})$. After incubation at $37^{\circ} \mathrm{C}$ for $18-24 \mathrm{~h}$, the diameters of the inhibition zone were interpreted according to the "Comité de la Société Française de l'Antibiogramme" (Cavallo et al., 2006) and followed by the recommendations of the National Committee for Clinical Laboratory Standards (NCCLS, 2002), the strains were categorized as susceptible or resistant to the drug. Escherichia coli ATCC 25922 was used as a quality control strain.

Determination of minimum inhibitory concentration (MIC). Minimum inhibitory concentration of six antibiotics (Sigma-Aldrich, USA): ampicillin sodium salt, erythromycin, tetracycline hydrochloride, streptomycin sulfate, gentamycin sulfate and chloramphenicol against Vibrio isolates were carried out using the broth microdilution method in Muller Hinton broth (bioMérieux, France) supplemented with $2 \% \mathrm{NaCl}$ (M7-A7; CLSI, 2006). All Vibrio strains were cultured on Trypticase Soy Agar plates (TSA) supplemented with 2\% $\mathrm{NaCl}$ and incubated at $30^{\circ} \mathrm{C}$ for $24-48 \mathrm{~h}$. The tested isolates were suspended in $0.85 \%$ saline to a turbidity equivalent to a $0.5 \mathrm{McF}$ arland standard $\left(1 \times 10^{8} \mathrm{CFU} / \mathrm{ml}\right)$ and serially diluted to obtain a concentration of $10^{5} \mathrm{CFU} / \mathrm{ml}$ in sterile $\mathrm{U}$ shaped bottom 96 -well microtiter plates containing the test concentrations of antibiotics $(0.125-256 \mathrm{mg} / \mathrm{l})$. The plates were incubated at $35^{\circ} \mathrm{C}$ for $18-20 \mathrm{~h}$ after which they were examined for the presence or absence of growth. E. coli ATCC 25922 was used as a control microorganism.

Chromosomal DNA preparation. Vibrio isolates were grown aerobically on TSA plates containing $1 \%$ $\mathrm{NaCl}$ at $37^{\circ} \mathrm{C}$ overnight. Genomic DNA was extracted using Wizard genomic DNA purification kit (Promega, France) according to the manufacturer's instructions.

Molecular characterization. Vibrio strains identified by microbiological methods were subjected to polymerase chain reaction assays to assess the presence of genes encoding the heat shocking protein 40 (Hsp-40) specific to V.alginolyticus, the outer membrane protein (Omp W) specific to $V$. cholerae and the regulatory toxin protein (ToxR) specific to V.parahaemolyticus (Table I). Amplification reactions contained $5 \times$ PCR buffer (Promega, France), $200 \mu \mathrm{mol} / \mathrm{l}$ of each desoxyribonucleotide triphosphate, $1.5 \mathrm{mmol} / \mathrm{l}$ of $\mathrm{MgCl}_{2}, 1 \mathrm{U}$ Taq polymerase (Promega, France), $1 \mu \mathrm{mol} / 1$ of each primer, and $2 \mu$ of the template in a final reaction volume of $25 \mu$ l. PCR amplifications were carried out in a thermal cycler (Eppendorf, Mastercycler per- 
Table I

PCR primers used in this study

\begin{tabular}{|c|c|c|c|}
\hline Target genes & PCR primer sequences $\left(5^{\prime}-3^{\prime}\right)$ & Product size (bp) & Reference \\
\hline$h s p-40$ & $\begin{array}{l}\text { VM-F, 5'-CAGGTTTGYTGCACGGCGAAGA-3' } \\
\text { V.al2-MmR, 5'-GATCGAAGTRCCRACACTMGGA-3' }\end{array}$ & 144 & Nhung et al., 2007 \\
\hline toxR-Vp & $\begin{array}{l}\text { toxR-Vp1, 5’-GTCTTCTGACGCAATCGTTG-3' } \\
\text { toxR-Vp1, 5'-ATACGAGTGGTTGCTGTCATG-3' }\end{array}$ & 678 & Lin et al., 1993 \\
\hline omp-W & $\begin{array}{l}\text { ompW1, 5'-CACCAAGAAGGTGACTTTATTGTG-3' } \\
\text { ompW2, 5'-GAACTTATAACCACCCGCG-3' }\end{array}$ & 588 & Nandi et al., 2000 \\
\hline toxRS & $\begin{array}{l}\text { toxR0, ATGAGTCATATTGGTACTTAAATT } \\
\text { toxS2, AACAGTACCGTAGAACCGTGA }\end{array}$ & 1397 & Sechi et al., 2000 \\
\hline tox $\mathrm{T}$ & $\begin{array}{l}\text { toxT1, TTGCTTGGTTAGTTATGAGAT } \\
\text { toxT2, TTGCAAACCCAGACTGATAT }\end{array}$ & 581 & Sechi et al., 2000 \\
\hline tox $\mathrm{R}$ & $\begin{array}{l}\text { toxR1, CCT TCG ATC CCC TAA GCA ATA C } \\
\text { toxR2, AGG GTT AGC AAC GAT GCG TAA G }\end{array}$ & 779 & Rivera et al., 2001 \\
\hline toxS & $\begin{array}{l}\text { toxS1, CCACTGGCGGACAAAATAACC } \\
\text { toxS2, AACAGTACCGTAGAACCGTGA }\end{array}$ & 640 & Sechi et al., 2000 \\
\hline$z o t$ & $\begin{array}{l}\text { zot1, ACGTCTCAGACATCAGTATCGAGTT } \\
\text { zot2, ATTTGGTCGCAGAGGATAGGCCT }\end{array}$ & 198 & Colombo et al., 1994 \\
\hline ace & $\begin{array}{l}\text { ace1, GCTTATGATGGACACCCTTTA } \\
\text { ace2, TTTGCCCTGCGAGCGTTAAAC }\end{array}$ & 284 & Colombo et al., 1994 \\
\hline$t c p \mathrm{P}$ & $\begin{array}{l}\text { tcpP1, CGAATGCAGTAATCAAGTCT } \\
\text { tcpP2, CAGTCAGCTTCATCAACAAT }\end{array}$ & 320 & Sechi et al., 2000 \\
\hline$t c p \mathrm{~A}$ & $\begin{array}{l}\text { tcpA1, CACGATAAGAAAACCGGTCAAGAG } \\
\text { tcpA2, ACCAAATGCAACGCCGAATGGAGC }\end{array}$ & 617 & Keasler and Hall, 1993 \\
\hline$v p i$ & $\begin{array}{l}\text { VPI1, GCAATTTAGGGGCGCGACGT } \\
\text { VPI2, CCGCTCTTTCTTGATCTGGTAG }\end{array}$ & 680 & Sechi et al., 2000 \\
\hline $\operatorname{ctx} \mathrm{A}$ & $\begin{array}{l}\text { ctx2, CGGGCAGATTCTAGACCTCCTG } \\
\text { ctx3, CGATGATCTTGGAGCATTCCCAC }\end{array}$ & 563 & Fields et al., 1992 \\
\hline th & $\begin{array}{l}\text { tlhf1, AGC GGA TTA TGC AGA AGC AC } \\
\text { tlhr2, ATC TCA AGC ACT TTC GCA CG }\end{array}$ & 150 & Xie et al., 2005 \\
\hline trh & $\begin{array}{l}\text { trhf1, TTG GCT TCG ATA TTT TCA GTA TCT } \\
\text { trhr1, CAT AAC AAA CAT ATG CCC ATT TCC G }\end{array}$ & 500 & Bej et al., 1999 \\
\hline$t d h$ & $\begin{array}{l}\text { tdhf1, CCA TTC TGG CAA AGT TAT T } \\
\text { tdhr1, TTC ATA TGC TTC TAC ATT AAC }\end{array}$ & 534 & Xie et al., 2005 \\
\hline
\end{tabular}

sonal). The reaction mixture was subjected to an amplification of 35 cycles. Apart from the primer annealing temperature, each cycle consisted of denaturation at $94^{\circ} \mathrm{C}$ for $30 \mathrm{sec}$, annealing for $30 \mathrm{sec}$, and primer extension at $72^{\circ} \mathrm{C}$ for $1 \mathrm{~min}$, then the mixtures were kept at $72^{\circ} \mathrm{C}$ for $10 \mathrm{~min}$. The annealing temperature was $60^{\circ} \mathrm{C}$ for $h s p-40$ and $64^{\circ} \mathrm{C}$ for ompW and toxR. PCR products were electrophoresed through $1.5 \%$ agarose gel to resolve the amplified products which were visualized under UV light after ethidium bromide staining.

Virulence gene. Oligonucleotide primers used in this study were listed in Table I. Amplification was carried out in a thermal cycler (eppendorf, Mastercycler personal) with a standard PCR reaction mixture that contained $10 \mu \mathrm{l}$ of $5 \times \mathrm{PCR}$ reaction buffer (Promega, France), $200 \mu \mathrm{mol} / \mathrm{l}$ of each of the four dNTPs, $1.5 \mu \mathrm{mol} / 1 \mathrm{MgCl}_{2}$ (Promega, France), $1 \mu \mathrm{mol} / \mathrm{l}$ of each primer, $1 \mu$ l extracted DNA (50 ng), $1.25 \mathrm{U}$ Taq polymerase (Promega, France) and sterile ultrapure water to make the volume to $50 \mu \mathrm{l}$. The mixtures were incubated for $5 \mathrm{~min}$ at $94^{\circ} \mathrm{C}$, followed by 35 cycles of amplification. Except for the primer annealing temperature, each cycle consisted of denaturation at $94^{\circ} \mathrm{C}$ for $40 \mathrm{sec}$, annealing for $40 \mathrm{sec}$, and primer extension at $72^{\circ} \mathrm{C}$ for $1 \mathrm{~min}$ and the mixtures were kept at $72^{\circ} \mathrm{C}$ for $10 \mathrm{~min}$. The annealing temperature was $48^{\circ} \mathrm{C}$ for $t d h, 54^{\circ} \mathrm{C}$ was used for toxRS, toxR, tox $\mathrm{T}$ and $t h, 58^{\circ} \mathrm{C}$ was used for tcp $\mathrm{P}, t c p \mathrm{~A}$, to $\mathrm{S}$, trh and ace whereas the temperature was $60^{\circ} \mathrm{C}$ for $v p i$, zot and ctxA. The amplified products were electrophoresed in a $1.6 \%$ agarose gel at $90 \mathrm{~V}$ for $30 \mathrm{~min}$, stained with ethidium bromide then visualized and photographed using Gel Doc XR apparatus (BioRad, Milan, Italy).

Adherence to PE and PVC surfaces. The quantitative estimate of biofilm formation of $V$. alginolyticus strains on PE and PVC surfaces was determinate using the protocol described by Cerca et al. (2006). Vibrio strains from fresh agar plates were harvested with sterile 
PBS and diluted to a standard concentration equal to an $\mathrm{OD}$ of 1.0 at $540 \mathrm{~nm}\left(1 \times 10^{9} \mathrm{CFU} / \mathrm{ml}\right)$. The $1 \mathrm{~cm} \mathrm{PE}$ and PVC squares were inserted in the bottom of 24-well microtitre plates (Greiner Bio-One Cellstar, Germany) and $2 \mathrm{ml}$ of each cell suspension was added to each well. Adhesion to each material was allowed to occur for $2 \mathrm{~h}$ at room temperature, with gentle shaking.

Negative control wells without bacterial cells were filled with PBS. At the end of the experiment, each well was washed twice with PBS to remove non-adherent or loosely adherent bacteria. After the last wash the pieces were removed from each well and immersed in a new microtiter plate with $1 \mathrm{ml}$ of $98 \%$ (w/v) methanol in each well (Henriques et al., 2005). The methanol was discarded after $15 \mathrm{~min}$ of contact and the pieces were allowed to dry at room temperature. Aliquots of crystal violet were added to each well and incubated for $5 \mathrm{~min}$. After the pieces were washed in water, they were left to dry, then immersed in $1 \mathrm{ml}$ of $33 \%$ acetic acid to release and dissolve the stain. The OD of the obtained solution was measured at $570 \mathrm{~nm}$ using a spectrophotometer (Jenway 6405 uv/vis). All strains were tested in triplicate, and the bacteria were classified according to Stepanovic et al. (2000) as follows (0): $\mathrm{OD} \leq \mathrm{ODc}$; weakly adherent $(+)$ : $\mathrm{ODc}<\mathrm{OD} \leq 2 \times \mathrm{ODc}$; moderately adherent $(++): 2 \times \mathrm{ODc}<\mathrm{OD} \leq 4 \times \mathrm{ODc}$; and strongly adherent $(+++): 4 \times \mathrm{ODc} \leq \mathrm{OD}$. This classification was based on the cut-off OD (ODc) value defined as three standard deviation values above the OD of the negative control.

Cell culture conditions. Two cell monolayers were used to examine the adhesive properties of Vibrio strains: Hep-2 (human larynx carcinoma) and Vero (kidney epithelial cells of African Green Monkey). For the cytotoxicity assay, we used Vero cells and HeLa (human cervical epitheloid carcinoma) cells.

The cells were grown in MEM (Minimum Essential Medium, Sigma) supplemented with $10 \%$ of foetal calf serum (Sigma), 1\% of antibiotic solution (streptomycin-penicillin $5000 \mathrm{U}$, Sigma), and 1\% of non-essential aminoacids (Sigma). Cells were seeded on 24-well tissue culture plates $\left(2 \times 10^{4} \mathrm{cell} / \mathrm{ml}\right)$, and incubated at $37^{\circ} \mathrm{C}$ in $5 \% \mathrm{CO}_{2}$ for $24 \mathrm{~h}$ (Baffone et al., 2005).

Adherence assay. Bacterial adherence was performed as described previously by Snoussi et al. (2008). Briefly, $100 \mu \mathrm{l}$ of $10^{7}$ cells $/ \mathrm{ml}$ was added to Vero and Hep- 2 cells and the 24 -well plates were incubated at $37^{\circ} \mathrm{C}$ for $3 \mathrm{~h}$ in $5 \% \mathrm{CO}_{2}$. The cells were washed three times in sterile PBS to remove non-adherent bacteria, fixed in methanol and stained with Giemsa for microscopic examination under oil immersion. Uninoculated cell lines served as negative controls. All organisms were tested twice. The adhesion index was assayed as $\mathrm{NA}=$ no adhesive $(0-10$ bacteria/cells); $\mathrm{W}=$ weak adhesion (10-20 bacteria/cells); $\mathrm{M}=$ medium adhesion (20-50 bacteria/cells); $\mathrm{S}=$ strong adhesion (50-100 bacteria/cells).

Cytotoxicty assay. In vitro cytotoxicity was examined on HeLa and Vero cell lines as performed by Baffone et al. (2005). Vibrio isolates were inoculated in TSB (Bio-Rad, France) supplemented with $1 \%$ of $\mathrm{NaCl}$, and incubated at $37^{\circ} \mathrm{C}$ for $18-24 \mathrm{~h}$. At the end of incubation, each flask contents were transferred to sterile tubes $(50 \mathrm{ml})$ and centrifuged at $3000 \mathrm{rpm}$ for $15 \mathrm{~min}$. The supernatant was filtered through a $0.22 \mu \mathrm{m}$ pore size filter membrane (Millipore, Germany). The bacterial cell-free filtrates were serially diluted (dilutions of 1:10, 1:50 and 1:100), were added to HeLa and Vero cells, previously washed in $\mathrm{PBS}$, and incubated at $37^{\circ} \mathrm{C}$ in $5 \% \mathrm{CO} 2$ for $24 \mathrm{~h}$. At the end of incubation, cells were observed under light inverted microscopy and checked for cytotoxic effect (rounding and shrinking to $\geq 50 \%$ of cells). All tests were performed in duplicate. The filtrates showing cytotoxic activity at a 1:10 dilution were considered to be weak (W) producers of toxin, those at a 1:50 dilution were moderate $(\mathrm{M})$ producers, and those at a 1:100 dilution were strong $(\mathrm{S})$ producers (Barbieri et al., 1999).

Statistical test. All data were analyzed with SPSS for Windows, version 16.0. The correlation between presence and absence of the virulence genes was studied by the Crosstabs method. For all test P-values $<0.05$ were considered statistically significant.

\section{Results}

A total of 65 Vibrio isolates were obtained on the selective TCBS agar plates and then they were characterized through the API 20E miniaturized system. Three environmental Vibrio species were identified on the basis of their biochemical profile as $V$. alginolyticus $(\mathrm{n}=48)$, V.cholerae $(\mathrm{n}=12)$ and V.parahaemolyticus $(\mathrm{n}=5)$. The majority of Vibrio isolates were positive for lysine decarboxylase, indole production, glucose fermentation and mannitol fermentation. V. cholerae and V. parahaemolyticus strains gave positive results with ornithine decarboxylase and gelatinase. The five V.parahaemolyticus isolates were able to utilize citrate and to assimilate rhamnose (Table II). All Vibrio strains tolerated low concentrations of $\mathrm{NaCl}$ (2 and 4\%). While only $5(41.66 \%)$ V. cholerae strains and 4 (80\%) V.parahaemolyticus strains grow in a nutrient broth prepared with $6 \%$ $\mathrm{NaCl}$. Of the $48 \mathrm{~V}$. alginolyticus isolates, 12 (25\%) were capable of growing at $10 \% \mathrm{NaCl}$ added to a nutrient broth. Vibrio isolates produced several hydrolytic exoenzymes such as amylase, lecithinase, lipase, caseinase, gelatinase and Dnase. Thirty seven of the forty-eight (77.08\%) V. alginolyticus and 2/12 (16.66\%) V.cholerae isolates were $\beta$-hemolytic. The PCR-based identification 
Table II

Biochemical and enzymatic characterization of Vibrio isolates

\begin{tabular}{|c|c|c|c|c|}
\hline \multicolumn{2}{|c|}{ Characteristic } & $\begin{array}{l}\text { V. alginolyticus } \\
\text { no. }(\%)^{\mathrm{a}}\end{array}$ & $\begin{array}{l}\text { V. cholerae } \\
\text { no. }(\%)^{\mathrm{a}}\end{array}$ & $\begin{array}{c}\text { V.parahaemolyticus } \\
\text { no. }(\%)^{\mathrm{a}}\end{array}$ \\
\hline \multicolumn{2}{|c|}{ No. of tested strains } & 48 & 12 & 5 \\
\hline \multicolumn{2}{|l|}{ Gram } & - & - & - \\
\hline \multicolumn{2}{|l|}{ Motility } & + & + & + \\
\hline \multicolumn{2}{|l|}{ Oxydase } & + & + & + \\
\hline \multicolumn{2}{|c|}{$\beta$-Galactosidase } & 0 & $12(100)$ & $3(60)$ \\
\hline \multicolumn{2}{|c|}{ Adenine dehydrolase } & 0 & 0 & 0 \\
\hline \multicolumn{2}{|c|}{ Lysine decarboxylase } & $47(97.91)$ & $12(100)$ & $5(100)$ \\
\hline \multicolumn{2}{|c|}{ Ornithine decarboxylase } & $24(50)$ & $12(100)$ & $5(100)$ \\
\hline \multicolumn{2}{|c|}{ Citrate utilization } & $8(16.66)$ & $10(83.33)$ & $5(100)$ \\
\hline \multicolumn{2}{|c|}{$\mathrm{H}_{2} \mathrm{~S}$ production } & $4(8.33)$ & $2(16.66)$ & 0 \\
\hline \multicolumn{2}{|c|}{ Urea hydrolysis } & 0 & 0 & $1(20)$ \\
\hline \multicolumn{2}{|c|}{ tryptophan deaminase } & $6(12.5)$ & 0 & 0 \\
\hline \multicolumn{2}{|c|}{ Indole production } & $48(100)$ & $12(100)$ & $5(100)$ \\
\hline \multicolumn{2}{|c|}{ Voges Proskauer } & $10(20.83)$ & $3(25)$ & 0 \\
\hline \multicolumn{2}{|l|}{ Gelatinase } & $32(66.66)$ & $12(100)$ & $5(100)$ \\
\hline \multicolumn{2}{|c|}{ Fermentation of: Glucose } & $48(100)$ & $12(100)$ & $5(100)$ \\
\hline \multicolumn{2}{|c|}{ Mannitol } & $47(97.91)$ & $12(100)$ & $5(100)$ \\
\hline \multicolumn{2}{|c|}{\begin{tabular}{|c|} 
Inositol \\
\end{tabular}} & 0 & 0 & 0 \\
\hline \multicolumn{2}{|c|}{\begin{tabular}{|c|} 
Sorbitol \\
\end{tabular}} & $4(8.33)$ & 0 & 0 \\
\hline \multicolumn{2}{|c|}{ Rhamnose } & 0 & 0 & $5(100)$ \\
\hline \multicolumn{2}{|c|}{ Sucrose } & $48(100)$ & $12(100)$ & 0 \\
\hline \multicolumn{2}{|c|}{\begin{tabular}{|c|} 
Melibiose \\
\end{tabular}} & 0 & 0 & 0 \\
\hline \multicolumn{2}{|c|}{ Amygdalin } & $21(43.75)$ & $4(33.33)$ & $4(80)$ \\
\hline \multicolumn{2}{|c|}{ Arabinose } & 0 & 0 & $3(60)$ \\
\hline \multirow[t]{2}{*}{ O/129: } & $10 \mu \mathrm{g}$ & $\mathrm{R}$ & $\mathrm{R}$ & $\mathrm{R}$ \\
\hline & $150 \mu \mathrm{g}$ & $S$ & $S$ & $S$ \\
\hline Growth at: & $0 \% \mathrm{NaCl}$ & 0 & 0 & 0 \\
\hline & $2 \% \mathrm{NaCl}$ & $48(100)$ & $12(100)$ & $5(100)$ \\
\hline & $4 \% \mathrm{NaCl}$ & $48(100)$ & $12(100)$ & $5(100)$ \\
\hline & $6 \% \mathrm{NaCl}$ & $48(100)$ & $5(41.66)$ & $4(80)$ \\
\hline & $8 \% \mathrm{NaCl}$ & $48(100)$ & 0 & 0 \\
\hline & $10 \% \mathrm{NaCl}$ & $12(25)$ & 0 & 0 \\
\hline Growth at: & $23^{\circ} \mathrm{C}$ & $48(100)$ & $12(100)$ & $5(100)$ \\
\hline & $37^{\circ} \mathrm{C}$ & $48(100)$ & $12(100)$ & $5(100)$ \\
\hline Exoenzymes: & Amylase & $37(77.08)$ & $9(75)$ & $3(60)$ \\
\hline & Lecithinase & $41(85.41)$ & $12(100)$ & $4(80)$ \\
\hline & Lipase & $48(100)$ & $12(100)$ & $5(100)$ \\
\hline & Caseinase & $48(100)$ & $10(83.33)$ & $4(80)$ \\
\hline & Gelatinase & 44 (91.66) & $10(83.33)$ & $5(100)$ \\
\hline & Dnase & $48(100)$ & $12(100)$ & $5(100)$ \\
\hline & $\beta$-hemolytic & $37(77.08)$ & $2(16.66)$ & 0 \\
\hline
\end{tabular}

a - Number and percentage of positive tests; $\mathrm{S}$ - sensitive; R - resistant.

of studied Vibrio strains yielded amplicon size of 144, 588 and 678 bp for V. alginolyticus, V.parahaemolyticus and $V$. cholerae, respectively (Fig. 1).

Antibiogram patterns obtained for the Vibrio spp. are presented in Table III. Tests for antimicrobial sus- ceptibility revealed that bacterial strains belonging to different species of Vibrio genera exhibited some common pattern of antibiotic resistance or susceptibility. In fact, all strains displayed a total resistance to ampicillin and more than $70 \%$ of them showed a significant 
Table III

Antibiotic resistance pattern expressed in (\%) and minimum inhibitory concentration of Vibrio strains expressed in $\mathrm{mg} / \mathrm{L}$ (\%)

\begin{tabular}{|c|c|c|c|}
\hline Antibiotics & $\begin{array}{l}\text { V. alginolyticus } \\
\quad(\mathrm{n}=48)\end{array}$ & $\begin{array}{l}\text { V. cholerae } \\
(\mathrm{n}=12)\end{array}$ & $\begin{array}{l}\text { V.parahaemolyticus } \\
\qquad(\mathrm{n}=5)\end{array}$ \\
\hline Ampicillin $(10 \mu \mathrm{g})$ & 100 & 100 & 100 \\
\hline Chloramphenicol $(30 \mu \mathrm{g})$ & 62.5 & 33 & 0 \\
\hline Cotrimoxazole $(25 \mu \mathrm{g})$ & 58.33 & 0 & 0 \\
\hline Gentamicin $(10 \mu \mathrm{g})$ & 75 & 25 & 0 \\
\hline Nalidixic acid $(30 \mu g)$ & 70.8 & 75 & 80 \\
\hline Streptomycin $(10 \mu \mathrm{g})$ & 83.3 & 75 & 100 \\
\hline Tetracyclin $(30 \mu \mathrm{g})$ & 83.3 & 25 & 0 \\
\hline Erythromycin $(15 \mu \mathrm{g})$ & 100 & 75 & 80 \\
\hline Kanamycin $(30 \mu \mathrm{g})$ & 95.8 & 16.6 & 60 \\
\hline Carbenicillin $(100 \mu \mathrm{g})$ & 100 & 25 & 40 \\
\hline \multirow[t]{5}{*}{ Ampicillin } & $16(12.5)$ & $16(33.3)$ & $16(80)$ \\
\hline & $32(35.4)$ & $32(41.6)$ & $32(20)$ \\
\hline & $64(22.9)$ & $64(16.6)$ & - \\
\hline & $128(20.8)$ & $128(8.3)$ & - \\
\hline & $256(8.3)$ & - & - \\
\hline \multirow[t]{5}{*}{ Erythromycin } & $16(20.8)$ & $4(33.3)$ & $4(40)$ \\
\hline & $32(39.6)$ & $8(25)$ & $8(20)$ \\
\hline & $64(22.9)$ & $16(25)$ & $16(20)$ \\
\hline & $128(16.6)$ & $32(16.6)$ & - \\
\hline & - & - & - \\
\hline \multirow[t]{5}{*}{ Tetracyclin } & $2(10.4)$ & $0.5(16.6)$ & $0.5(20)$ \\
\hline & $4(16.6)$ & $1(33.3)$ & $1(80)$ \\
\hline & $8(41.6)$ & $2(16.6)$ & - \\
\hline & $16(25)$ & $4(8.3)$ & - \\
\hline & $32(6.2)$ & $8(8.3)$ & - \\
\hline \multirow[t]{5}{*}{ Streptomycin } & $4(6.2)$ & $2(33.3)$ & $4(80)$ \\
\hline & $8(10.4)$ & $4(41.6)$ & $16(20)$ \\
\hline & $16(45.8)$ & $8(16.6)$ & - \\
\hline & $32(27)$ & $16(8.3)$ & - \\
\hline & $64(10.4)$ & - & - \\
\hline \multirow[t]{4}{*}{ Gentamycin } & $4(12.5)$ & $1(25)$ & $1(20)$ \\
\hline & $8(35.4)$ & $2(33.3)$ & $2(80)$ \\
\hline & $16(43.7)$ & $4(16.6)$ & - \\
\hline & $32(8.3)$ & $8(25)$ & - \\
\hline \multirow[t]{4}{*}{ Chloramphenicol } & $1(18.7)$ & $0.5(16.6)$ & $0.25(20)$ \\
\hline & $2(18.7)$ & $1(25)$ & $0.5(20)$ \\
\hline & $4(31.2)$ & $2(50)$ & $1(60)$ \\
\hline & $8(31.2)$ & $4(8.3)$ & - \\
\hline
\end{tabular}

resistance to streptomycin, nalidixic acid and erythromycin. V.alginolyticus strains had the highest multi-drug resistance showing a strong resistance to ampicillin, erythromycin, carbenicillin, streptomycin, kanamycin and tetracycline. The resistance to chloramphenicol was observed in $62.5 \%$ of the analyzed V. alginolyticus strains and in $33 \%$ of the V. cholerae isolates.
The MIC results for Vibrio isolates were summarized in the Table III. MIC values of antimicrobials observed throughout the study showed that all investigated isolates were highly susceptible to chloramphenicol $(0.25-8 \mathrm{mg} / \mathrm{l})$ and were moderately sensitive to both tetracyclin $(0.5-32 \mathrm{mg} / \mathrm{l})$ and gentamycin $(0.5-32 \mathrm{mg} / \mathrm{l})$. The MIC values of different tested anti- 


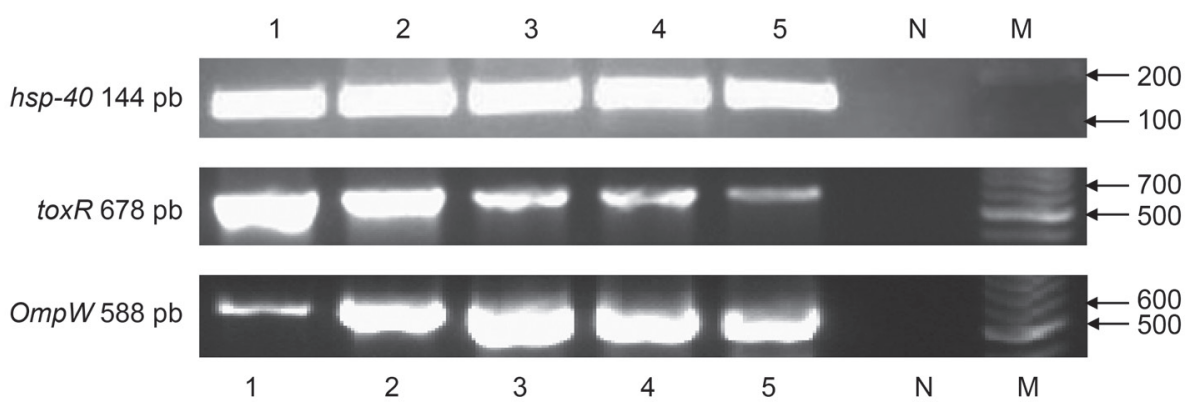

Fig. 1. Agarose gel electrophoresis of $1.5 \%$ agarose of the amplification products of isolates obtained with PCR for the Hsp-40 (V. alginolyticus: $1, \mathrm{AMa}_{1}, 2, \mathrm{BN}_{3}, 3, \mathrm{CJ} 4,5, \mathrm{CJ}_{3}, 6, \mathrm{DS}_{3}$ ); PCR for the toxR (V.parahaemolyticus: $1, \mathrm{AA}_{2}, 2, \mathrm{DM}_{4}, 3, \mathrm{DJ}_{1}, 4, \mathrm{CAt}_{4}, 5, \mathrm{BJ}_{3}$ ) and PCR for the OmpW (V.cholerae: $1, \mathrm{BJ}_{1}, 2, \mathrm{AM}_{1}, 3, \mathrm{BN}_{2}, 4, \mathrm{CF}_{3}, 5, \mathrm{BJ}_{2}$ ). $\mathrm{N}$, negative control, $\mathrm{M}$, molecular weight marker 100 bp ladder (Promega, France).

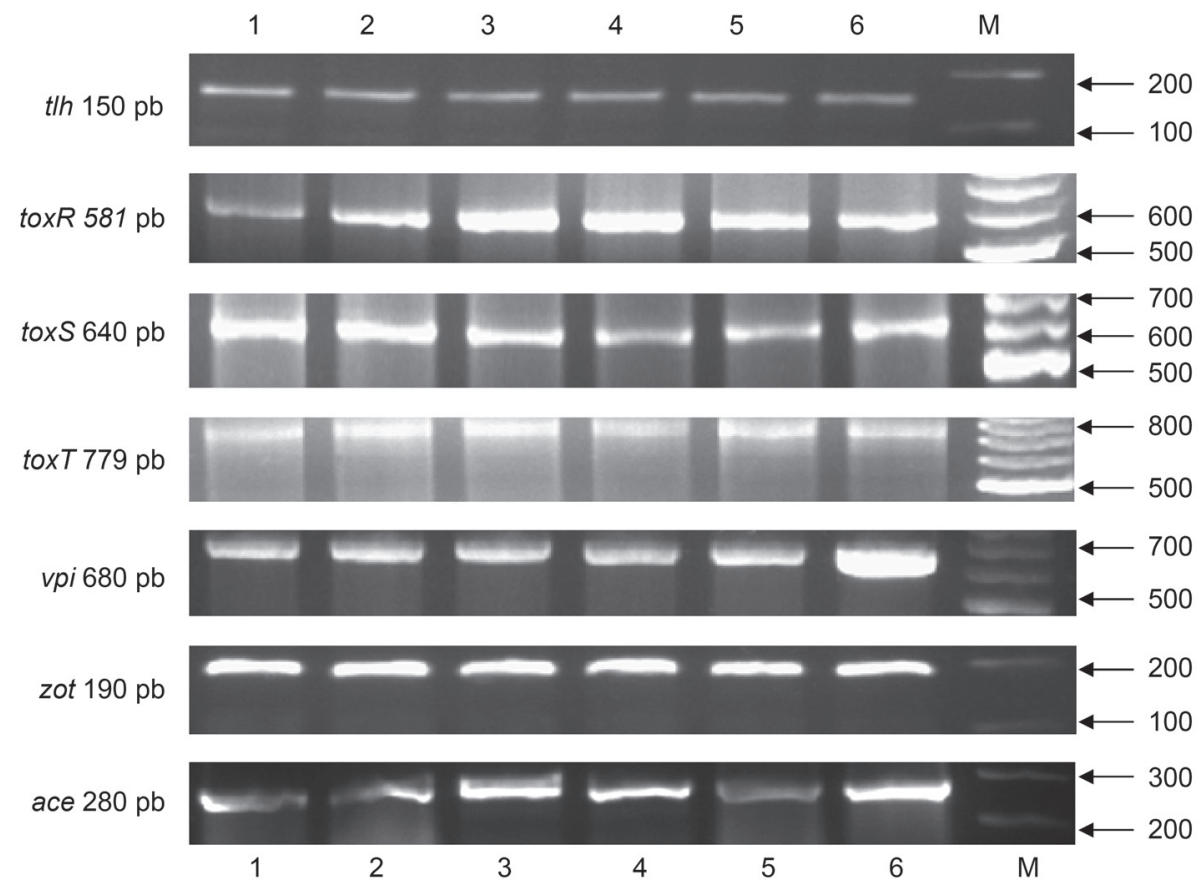

Fig. 2. Virulence genes espression of Vibrio strains isolated from Monastir lagoon. Agarose gel electrophoresis (1.6\% agarose) of the ace (V.alginolyticus: $1, \mathrm{AMa}_{1}, 2, \mathrm{BN}_{3}, 3, \mathrm{CJ}_{4}, 4, \mathrm{DMa}_{3}, 5$, $\mathrm{BJt}, 6, \mathrm{CO}_{1}$ ), the $z$ ot (V.alginolyticus: $1, \mathrm{AJ}_{3}, 2, \mathrm{BAt}_{3}, 3, \mathrm{CAt}_{3}, 4, \mathrm{DS}_{3}, 5, \mathrm{AAt}_{2}, 6, \mathrm{DAt}_{3}$ ), the $v p i$ (V. alginolyticus: $1, \mathrm{AAt}_{1}, 2, \mathrm{AAt}_{2}, 3, \mathrm{BJ}_{2}, 4, \mathrm{CJ}_{3}, 5, \mathrm{DJt}_{4}, 6, \mathrm{DS}_{3}$ ). the toxT (V.cholera: $1, \mathrm{BJ}, 2, \mathrm{AJt}_{3}$, $3, \mathrm{BN}_{2}$ and V.aliginolyticus: $4, \mathrm{AMa}_{1}, 5, \mathrm{CJ}_{3}, 6, \mathrm{DS}_{3}$ ), the toxS (V.cholera: $1, \mathrm{CF}_{3}, 2, \mathrm{AM}_{1}, 3, \mathrm{BJ}_{2}$, V.parahaemolyticus: $4, \mathrm{CAt}_{4}$ and V. alginolyticus: $5, \mathrm{CAt}_{3}, 6, \mathrm{DMa}_{1}$ ), the toxR (V.cholera: $1, \mathrm{CF}_{3}, 2$, $\mathrm{AM}_{1}, 3, \mathrm{BJ}_{2}$, V.parahaemolyticus: $4, \mathrm{CAt}_{4}$ and V. alginolyticus: $5, \mathrm{BJt}_{3} ; 6, \mathrm{CMa}_{4}$ ) and the th V.parahaemolyticus: $1, \mathrm{AA}_{2}, 2, \mathrm{DM}_{4}, 3, \mathrm{DJ}_{1}, 4, \mathrm{CAt}_{4}$, V. alginolyticus: $5, \mathrm{BM}_{2}, 6, \mathrm{AJ}_{3}$ ). $\mathrm{M}$, molecular weight marker 100 bp ladder (Promega, France).

biotics for V.parahaemolyticus strains were lower than those found among other Vibrio species. In other hand, the vast majority of $V$. alginolyticus isolates showed a strong resistance to ampicillin $(87.4 \% \geq 32 \mathrm{mg} / \mathrm{l})$; erythromycin $(79 \% \geq 32 \mathrm{mg} / \mathrm{l})$; tetracyclin $(31.5 \% \geq$ $\geq 16 \mathrm{mg} / \mathrm{l})$; streptomycin $(37.4 \% \geq 32 \mathrm{mg} / \mathrm{l})$ and genta$\operatorname{mycin}(52 \% \geq 16 \mathrm{mg} / \mathrm{l})$.

The distribution of V.cholerae and V.parahaemolyticus virulence-associated genes among the tested Vibrio strains was presented in the Table IV. The presence of the tox $\mathrm{R}$ and the tox $\mathrm{S}$ genes was detected in the majority of $V$. cholerae ( $100 \%$ and $83 \%$, respectively) strains and V. alginolyticus (73\% and 58\%, respectively) strains, while only one $V$. parahaemolyticus isolates was positive to these genes (Fig. 2). The toxT fragment was amplified from the chromosome of 10/12 (83\%) V. cholerae strains whereas $13 / 48$ (27\%) V.alginolyticus isolates gave a positive result to this gene. Only the V.alginolyticus strains exhibited the presence of three V. cholerae virulence genes: vpi (25\%), ace (19\%) and zot (29\%). 


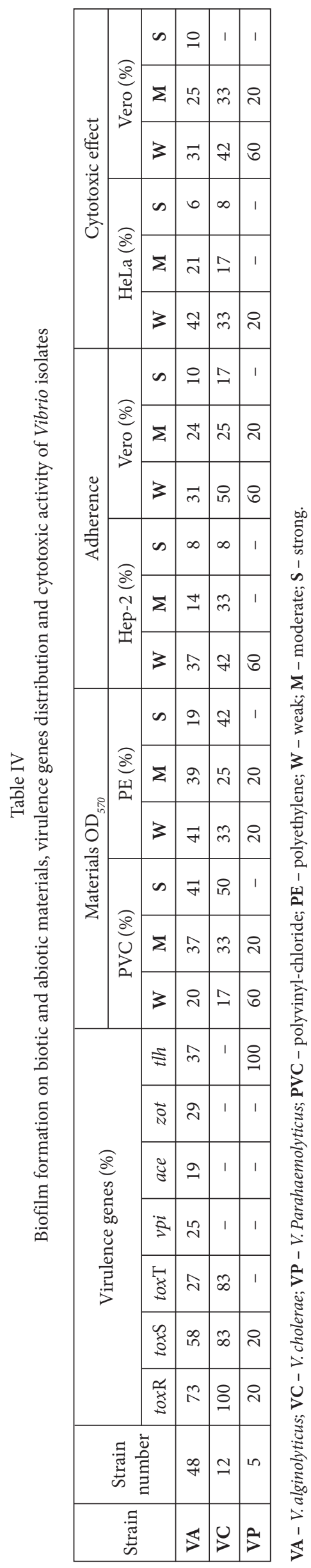

All $V$.parahaemolyticus isolates were positive to the th virulence gene, while 18/48 V.alginolyticus strains possessed this gene. The crosstabs method revealed a significant relationship $(\mathrm{P}<0.05)$ between the presence of the tox $\mathrm{R}$ gene and the tox $\mathrm{S}$ gene. On other hand, a positive correlation was observed between the presence of the vpi gene and the tox $\mathrm{R}$ gene $(\mathrm{P}=0.039)$, tox $\mathrm{S}$ gene $(\mathrm{P}=0.007)$ and the tox $\mathrm{T}$ gene $(\mathrm{P}=0.005)$. However, no significant relationship was observed between the presence of $V$. cholerae and V.parahaemolyticus virulence genes. All isolates gave negative results for the amplification of toxRSI tcpP, tcpA, $t d h$ and $t r h$.

The results of the biofilm formation by Vibrio species on PVC and PE surfaces showed that V.cholerae and V.alginolyticus strains were strongly adhesive to both abiotic materials than other isolates. In fact, $50 \%(6 / 12)$ of $V$. cholerae isolates and $41 \%(20 / 48)$ of $V$. alginolyticus exhibited high adherence ability to PVC pieces. V.cholerae isolates presented better adherence ability on PE surface than V.alginolyticus strains (42 and $19 \%$, respectively).

Adherence ability was observed in 11 of 12 (92\%) of the analyzed V.cholerae strains in Vero cells, while $10(83 \%)$ isolates were found adhesive when Hep-2 cell line was used. The other tested Vibrio species revealed that were lower adhesive to both cell lines than V. cholerae isolates. We also noted that only $V$. alginolyticus strains showed a strong adherence to Hep-2 cells (Table IV). About 2 of 48 (4\%) V. alginolyticus strains and one of $12(8 \%) V$.cholerae strains were able to adhere strongly to both epithelial cell lines (Fig. 3).

The cytotoxic activity of extracellular products (ECPs) of the three studied Vibrio species against HeLa and Vero cell lines showed that more than 60\% of $V$. alginolyticus strains have cytotoxic effect with different degrees to both epithelial cell lines. About 5 of 48 (10\%) V. alginolyticus isolates showed a strong cytotoxicity against Vero monolayer while only 3 strains gave the same results when Hep- 2 cells were used. However, most strains of V. cholerae and V. parahaemolyticus exhibited essentially weak and moderate cytotoxic activities (Table IV).

\section{Discussion}

The past two decades have witnessed remarkable increasing frequency of Vibrio species isolated from diseased aquatic animals and from human infections. $V$. alginolyticus is recognized as one of the major causative agent of vibriosis in cultured fish and shellfish in Mediterranean coastal environment (Gomez-Leon et al., 2005; Sonia and Lipton, 2012). Other studies reported that this specie is considered as an important human opportunistic pathogen usually associated with otitis 

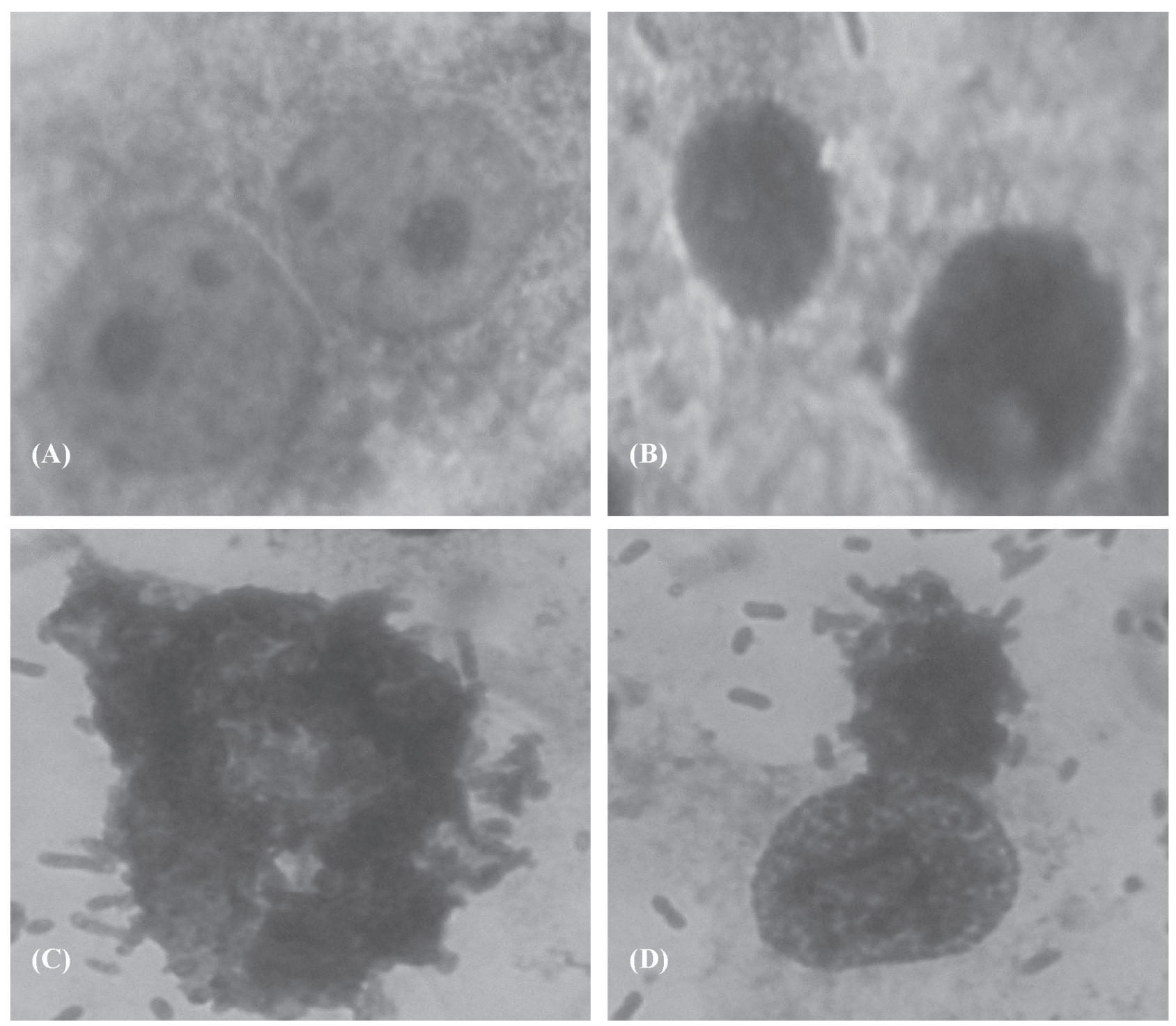

Fig. 3. Optic microscopy showing the high adherence ability of Vibrio alginolyticus (strain Bat4) to both Vero and Hep-2 cell lines. Giemsa stain: magnification $(\times 1000)$. (a) and (B): Negative control for Vero and Hep-2 cells. (C) and (D): Vibrio alginolyticus strain Bat4 strongly adhesive to Vero and Hep-2 cells respecctively.

externa, endophthalmitis and wound infections ( $\mathrm{Li}$ et al., 2009; Reilly et al., 2011). It's also well documented that V.cholerae and V.parahaemolyticus are most often incriminated in food-borne and waterborne gastroenteritis outbreaks (Nair et al., 2007; Yoder et al., 2008).

Sixty-five Vibrio spp. strains were isolated from water samples collected from the Monastir lagoon and biochemically characterized using the commercial miniaturized Api 20E kit. The phenotypic characteristics of Vibrio isolates were in accordance with those described previously by Snoussi et al. (2006). However, these findings are in discordance with Ben Kahla-Nakbi et al. (2007) who showed that a majority of V.alginolyticus isolates recovered from dead and moribund fish samples were negative to indole test. The environmental strains of V. alginolyticus, V. cholerae and V.parahaemolyticus were genetically identified to the species levels using the $h s p-40$, ompW and the tox $\mathrm{R}$ genes, respectively (Lin et al., 1993; Nandi et al., 2000).

In the present study, Vibrio isolates exhibited multidrug resistance to at least four antibiotics. Vaseerahan et al. (2005) carried a study of 80 Vibrio strains isolated from Indian shrimp culture ponds and hatcheries for determination of their susceptibility to the most used antibiotics in the shrimp farming, all tested isolates were resistant to ampicillin, which corroborate with our findings. Other studies, reported that V. alginolyticus strains showed resistance to erythromycin, streptomycin, gentamycin, tetracyclin and chloramphenicol (Gomathi et al., 2013; Mechri et al., 2013b). These data are in keeping with our results.

The MIC's obtained from the study showed that all Vibrio strains were sensitive to chloramphenicol (MIC's $\leq 8 \mathrm{mg} / \mathrm{l}$ ), while most of them expressed high 
rates of resistance to ampicillin (MIC's $\geq 32 \mathrm{mg} / \mathrm{l}$ ) and erythromycin (MIC's $\geq 8 \mathrm{mg} / \mathrm{l}$ ). In a previous study, Manjusha et al. (2005) reported strong resistance against amoxicillin, ampicillin, carbenicillin, cefuroxime, rifampicin and streptomycin in Vibrio spp. isolated from Indian coastal and brackish areas. Another study, showed that Vibrio isolates recovered from aquaculture structure expressed moderate resistance to chloramphenicol, gentamycin, tetracyclin and erythromycin (Akinbowale et al., 2006).

Previous work showed that Vibrio species represents an important recipient of some V.cholerae and $V$. parahaemolyticus virulence genes transfers (Xie et al., 2005). Snoussi et al. (2008), reported the diffusion of six $V$. cholerae virulence genes among $28 \mathrm{~V}$. alginolyticus strains isolated from the Mediterranean seawater. Our results corroborate with these findings and represents the first report describing higher frequencies of V.cholerae and V.parahaemolyticus virulence genes distribution, among environmental V.alginolyticus isolates, than observed previously (Ren et al., 2013; Khoudja et al., 2014). These data supports the evidence of genetic extensive exchange of virulence determinants between V.alginolyticus and other Vibrio species in marine and estuary environments.

Biofilm formation constitutes an efficient adaptive strategy utilized among numerous Vibrio species, which remarkably promotes bacterial persistence in the environment and/or colonization of eukaryotic hosts (Morris and Visick, 2010). In this study, V. cholerae and $V$. alginolyticus strains exhibited high capacity of adherence to both PVC and PE surfaces, while V. parahaemolyticus isolates showed low to moderate adhesion to the same materials. These data corroborate previous studies showing that environmental Vibrio species were able to form biofilm on abiotic surfaces of different degrees (Mechri et al., 2013a).

The attachment of bacterial pathogens to eukaryotic cells represents an essential first step in the colonization and the production of disease. This propriety seems to be diffused among Vibrio species (Scoglio et al., 2001; Mohammadi-Barzelighi et al., 2011). Our data showed that V.cholerae and V.alginolyticus isolates exhibited an important adherence ability to both tested cell lines. These findings may explain a possible interaction between these strains and the epithelial cell lines used in this study.

Several studies reported cytotoxic effects of extracellular products of some Vibrio spp. against a variety of cell lines (Hiyoshi et al., 2010; Mechri et al., 2013b). Our investigation showed that $V$. alginolyticus isolates exhibited the most important cytotoxic activity against Vero and HeLa cell lines. Balebona et al. (1998), suggested that cytotoxicity in cell lines can be directly related to the virulence of V. alginolyticus strains.

\section{Conclusions}

This study highlights the incidence of multiple antibiotic resistance in three environmental Vibrio species and the wide distribution of some $V$. cholerae and $V$.parahaemolyticus virulence genes among the studied strains. Besides, it is clearly shown that tested bacteria present a high ability to adhere to biotic and abiotic surfaces though at varying levels. These isolates exhibited also a significant cytotoxicity against HeLa and Vero cell lines.

\section{Literature}

Akinbowale O.L., H. Peng and M.D. Barton. 2006. Antimicrobial resistance in bacteria isolated from aquaculture sources in Australia. J. Appl. Microbiol. 100: 1103-1113.

Baffone W., E. Vittoria, R. Campana, B. Citterio, A. Casaroli and L. Pierfelice. 2005. Occurrence and expression of virulence related properties by environmental Vibrio spp. in vitro and in vivo systems. Food Control. 16: 451-457.

Balebona M.C., M.J. Andreu, M.A. Bordas, I. Zorrilla, M.A. Morinigo and J.J. Borrego. 1998. Pathogenicity of Vibrio alginolyticus for cultured gilt-head sea bream (Sparus aurata L.). Appl. Environ. Microbiol. 64: 4269-4275.

Barbieri E., L. Falzano, C. Fiorentini, A. Pianetti, W. Baffone, A. Fabbri, P. Matarrese, A. Casiere, M. Katouli, I. Kuhn and others. 1999. Occurrence, diversity, and pathogenicity of halophilic Vibrio spp. and non-O1 Vibrio cholerae from estuarine waters along the Italian adriatic coast. App. Envir. Microbio. 65: 2748-2753.

Barton C. and R. Acton. 2009. Hemochromatosis and Vibrio vulnificus wound infections. J. Clin. Gastroenterol. 43(9): 890-893.

Bej A.K., D.P. Patterson, C.W. Brasher, M.C. Vickery, D.D. Jones and C.A. Kaysner. 1999. Detection of total and hemolysinproducing Vibrio parahaemolyticus in shellfish using multiplex PCR amplification of $t$ th, $t d h$ and trh. J. Microbiol. Methods. 36: 215-225.

Ben Kahla-Nakbi A., K. Chaieb, A. Besbes, T. Zmantar and A. Bakhrouf. 2006. Virulence and enterobacterial repetitive intergenic consensus PCR of Vibrio alginolyticus strains isolated from Tunisian cultured gilthead sea bream and sea bass outbreaks. Vet. Microbiol. 117: 321-327.

Ben Kahla-Nakbi A., A. Besbes, K. Chaieb, M. Rouabhiab and A. Bakhrouf. 2007. Survival of Vibrio alginolyticus in seawater and retention of virulence of its starved cells. Mar. Environ. Res. 46: 469-478.

Cavallo J.D., H. Chardon, C. Chidiac, P. Choutet, P. Courvalin, H. Dabernat, H. Drugeon, L. Dubreuil, F. Goldstein, V. Jarlier and others. 2006. Antibiogram Committee of the French Microbiology Society. Report 2006 (in French). http://www.sfm-microbiologie. org/UserFiles/files/casfm_2006.pdf, 2014.10.01.

Cerca N., K.K. Jefferson, R. Oliveira, G.B. Pier and J. Azeredo. 2006. Comparative antibody-mediated phagocytosis of Staphylococcus epidermidis cells grown in a biofilm or in the planktonic state. I.A.I. 74: 4849-4855.

Clinical and Laboratory Standards Institute (CLSI). 2006. Wayne, PA: Clinical and Laboratory Standards Institute, Methods for dilution antimicrobial susceptibility tests for bacteria that grow aerobically. M7-A7. 26: 14-16.

Colombo M.M., S. Mastrandea, A. Santona, A.P. De Amdrade, S. Uzzau, S. Rubino and P. Cappuccinelli. 1994. Distribution of the 
ace, zot and ctxA toxin genes in clinical and environmental Vibrio cholerae. J. Fish. Dis. 170: 750-751.

Costa R.A., G.C. Silva, J.R.O. Piexoto, G.H.F. Vieira and R.H.S.F. Vieira. 2010; Quantification and distribution of Vibrio species in water from an estuary in Ceará-Brazil impacted by shrimp farming. Braz. J. Oceanogr. 58(3): 183-188.

Costerton J.W., Z. Lewandowski, D.E. Caldwell, D.R. Korber and H.M. Lappin-Scott. 1995. Microbial biofilms. Ann. Rev. Microbiol. 49: 711-745.

Fasano A., B. Baudry, D.W. Pumplin, S.S. Wasserman, B.D. Tall, J.M. Ketley and J.B. Kaper. 1991. Vibrio cholerae produces a second enterotoxin, which affects intestinal tight junctions. Proc. Natl. Acad. Sci. USA 88: 5242-5246.

Fields P.I., T. Popovic, K. Wachsmuth and O. Olsvik. 1992. Use of polymerase chain reaction for detection of toxigenic Vibrio cholerae $\mathrm{O} 1$ strains from the Latin American cholera epidemic. J. Clin Microbiol. 30: 2118-2121.

Gomathi R.S., R. Vinothkumar and K. Arunagiri. 2013. Isolation and identification vibrios from marine seafood samples. Int. J. Curr. Microbiol. App. Sci. 2(2): 36-43.

Gomez-Leon J., L. Villamil, M.L. Lemos, B. Novoa and A. Figueras. 2005. Isolation of Vibrio alginolyticus and Vibrio splendidus from aquacultured carpet shell clam (Ruditapes decussatus) larva associated with mass mortalities. Appl. Environ. Microbiol. 71(1) 98-104

Mohammadi-Barzelighi H., B. Bakhshi, A. Rastegar-Lariand and M.R. Pourshafie. 2011. Characterization of pathogenicity island prophage in clinical and environmental strains of Vibrio cholerae. J. Med. Microbiol. 60: 1742-1749.

Hall-Stoodley L., J.W. Costerton and P. Stoodley. 2004. Bacteria biofilms: from the natural environment to infectious diseases. Nat. Rev. Microbiol. 2: 95-108.

Henriques M., C. Sousa, M. Lira, M. Elisabete, R. Oliveira and J. Azeredo. 2005. Adhesion of Pseudomonas aeruginosa and Staphy lococcus epidermidis to silicone-hydrogel contact lenses. Optom. Vis. Sci. 82: 446-450.

Hiyoshi H., T. Kodama, T. Iida and T. Honda. 2010. Contribution of Vibrio parahaemolyticus virulence factors to cytotoxicity enterotoxicity, and lethality in mice. Infect. Immun. 78: 1772-1780. Hoffmann F., O. Larsen, V. Thiel, H.T. Rapp, T. Pape, W. Michaelis and J. Reitner. 2005. An anaerobic world in sponges. Geomicrobiol. J. 22: 1-10.

Keasler S.P. and R.H. Hall. 1993. Detecting and biotyping Vibrio cholerae $\mathrm{O} 1$ with multiplex polymerase chain reaction. Lancet 341 : 1661.

Khouadja S., E. Suffredini, B. Baccouche, L. Croci and A. Bakhrouf. 2014. Occurrence of virulence genes among Vibrio cholerae and Vibrio parahaemolyticus strains from treated wastewaters. Environ. Monit. Assess. 186: 6935-6945

Li X.C., Z.Y. Xiang, X.M. Xu, W.H. Yan and J.M. Ma. 2009 Endophthalmitis caused by Vibrio alginolyticus. J. Clin. Microbiol. 47(10): 3379-3381

Lin Z., K. Kumagai, K. Baba, J.J. Mekalanos and M. Nishibuchi. 1993. Vibrio parahaemolyticus has a homolog of the Vibrio chole rae toxRS operon that mediates environmentally induced regulation of the thermostable direct hemolysin gene. J. Bacteriol. 175 3844-3855.

Liu P.C., K.K. Lee and S.N. Chen. 1996. Pathogenicity of different isolates of Vibrio harveyi in tiger prawn, Penaeus monodon. Lett. Appl. Microbiol. 22: 413-416.

Manjusha S., G.B. Sarita, K.K. Elyas and M. Chandrasekaran. 2005. Multiple antibiotic resistances of Vibrio isolates from coastal and brackish water areas. A.J. Biochem. Biotechnol. 1: 201-206

Matsumoto C., J. Okuda, M. Ishibashi, M. Iwanaga, P. Vi Garg, T. Rammamurthy, H. Wong, A. DePaola, Y.B. Kim, M.J. Albert and others. 2000. Pandemic spread of an O3:K6 clone of Vibrio parahaemolyticus and emergence of related strains evidenced by arbitrarily primed PCR and toxRS sequence analyses. J. Clin. Microbiol. 38(2): 578-585.

Mechri B., A. Medhioub, M.N. Medhioub and M. Aouni. 2012. Diversity of Vibrionaceae associated with Ruditapes decussatus hatchery in Tunisia. Ann. Microbiol. 61(2): 597-606.

Mechri B., R. Mabrouki-Charfeddine, A. Medhioub, M.N. Medhioub and M. Aouni. 2013a. Adhesive properties and antibacterial susceptibility of Vibrio alginolyticus strains isolated from a Tunisian Ruditapes decussatus hatchery. A.J.M.R. 7(31): 4022-4030.

Mechri B., A. Medhioub, M.N. Medhioub and M. Aouni. 2013b. Genotypic Diversity, Antimicrobial resistance and screening of Vibrio cholerae molecular virulence markers in Vibrio alginolyticus strains recovered from a Tunisian Ruditapes decussatus hatchery. Pol. J. Microbiol. 62(3): 263-272.

Miller J.F., J.J. Mekalanos and S. Falkow. 1989. Coordinate regulation and sensory transduction in the control of bacterial virulence. Science 243: 916-922.

Miller V.L., R.K. Taylor and J.J. Mekalanos. 1987. Cholera toxin transcriptional activator toxR is a trans-membrane DNA binding protein. Cell 48: 271-279.

Morris A.R. and K.L. Visick. 2010. Control of biofilm formation and colonization in Vibrio fischeri: a role for partner switching? Environ. Microbiol. 12: 2051-2059.

Nair G.B. and J.C. Hormazabal. 2005. The Vibrio parahaemolyticus pandemic. Rev. Chil. Infectol. 22: 125-130.

Nair G.B., T. Ramamurthy, S.K. Bhattacharya, B. Dutta, Y. Takeda and D.A. Sack. 2007. Global dissemination of Vibrio parahaemolyticus serotype O3:K6 and its serovariants. Clin. Microbiol. Rev. 20: 39-48.

Nandi, B., R. K. Nandy, S. Mukhopadhyay, G. B. Nair, T. Shimada, and A.C. Ghose. 2000. Rapid method for species-specific identification of Vibrio cholerae using primers targeted to the gene of outer membrane protein ompW. J. Clin. Microbiol. 38: 4145-4151.

National Committee for Clinical Laboratory Standards (NCCLS). 2002 Performance standards for antimicrobial disk and dilution susceptibility tests for bacteria isolated from animals. Tentative standards. Document M31-T. NCCLS. Wayne.

Nhung P.H., M.M. Shah, K. Ohkusu, M. Noda, H. Hata, X.S. Sun, H. Iihara, K. Goto, T. Masaki, J. Miyasaka and T. Ezaki. 2007. DnaJ gene as a novel phylogenetic marker for identification of Vibrio species. J. Syst. Appl. Microbiol. 30: 309-315.

Ottaviani D., I. Bacchiocchi, L. Masini, F. Leoni, A. Carraturo, M. Giammarioli and G. Sbaraglia. 2001. Antimicrobial susceptibility of potentially pathogenic halophilic vibrios isolated from sea food. Int. J. Antimicrobial. Agents. 18: 135-140.

Peterson K.M. 2002. Expression of Vibrio cholerae virulence genes in response to environmental signals. Curr. Issues. Intest. Microbiol. 3: $29-38$.

Reboucas R.H., O.A. de Sousa, A.S. Lima, F.R. Vasconcelos, P.B. de Carvalho and R.H.S.F. Vieira. 2011. Antimicrobial resistance profile of Vibrio species isolated from marine shrimp farming environments (Litopenaeus vannamei) at Ceará, Brazil. Environ Res. 111(1): 21-24.

Reilly G.D., C.A. Reilly, E.G. Smith and C. Baker-Austin. 2011. Vibrio alginolyticus associated wound infection acquired in British water. Eurosurveillance. 16: 1-2.

Ren C., C. Hu, X. Jiang, H. Sun, Z. Zhao, C. Chen and P. Luo. 2013. Distribution and pathogenic relationship of virulence associated genes among Vibrio alginolyticus from the mariculture systems. Mol. Cell Probe. 27:164-168.

Rivera I.N.G., J. Chun, A. Huq, R.B. Sack and R.R. Colwell. 2001. Genotypes associated with virulence in environmental isolates of Vibrio cholera. Appl. Environ. Microbiol. 67: 2421-2429. 
Scoglio M.E., A. Di Pietro, I. Picerno, S. Delia, A. Mauro and P. Lagana. 2001. Virulence factors in Vibrios and Aeromonads isolated from seafood. New. Microbiol. 24: 273-280.

Sechi L.A., I. Dupre, A. Deriu, G. Fadda and S. Zanetti. 2000. Distribution of Vibrio cholerae virulence genes among different Vibrio species isolated in Sardinia., Italy. J. Appl. Microbiol. 88: 475-481.

Snoussi M., K. Chaieb, M. Rouabhia and A. Bakhrouf. 2006. Quantitative study, identification and antibiotics sensitivity of some Vibrionaceae associated to a marine fish hatchery. Ann. Microbiol. 56(4): 289-293.

Snoussi M., E. Noumi, D. Usai, L.A. Sechi, S. Zanetti and A. Bakhrouf. 2008. Distribution of some virulence related-properties of Vibrio alginolyticus strains isolated from Mediterranean seawater (Bay of Khenis, Tunisia): investigation of eight Vibrio cholerae virulence genes. World. J. Microbiol. Biotech. 24: 2133-2141.

Sonia A.S. and A.P. Lipton. 2012. Pathogenicity and antibiotic susceptibility of Vibrio species isolated from the captive-reared tropical marine ornamental blue damsel fish, Pomacentrus caeruleus (Quoy and Gaimard, 1825). Indian J. Geo-Marine Sci. 41: 348-354.
Stepanovic S., D. Vukovic, I. Dakic, B. Savic and M. ŠvabićVlahovic. 2000. A modified microtiter-plate test for quantification of staphylococcal biofilm formation. J. Microbiol. Methods. 40: 175-179. Trucksis M., J.E. Galen, J. Michalski, A. Fasano, and J.B. Kaper. 1993. Accessory cholera enterotoxin (ace), the third toxin of a V. cholerae virulence cassette. PNAS 90: 5267-5271.

Vaseeharan B., P. Ramasamy, T. Murugan and J.C. Chen. 2005. In vitro susceptibility of antibiotics against Vibrio spp. and Aeromonas spp. isolated from Penaeus monodon hatcheries and ponds. Int. J. Antimicrob. Agents. 26: 285-291.

Xie Z.Y., C.Q. Hu, C. Chen, L.P. Zhang and C.H. Ren. 2005. Investigation of seven Vibrio virulence genes among Vibrio alginolyticus and Vibrio parahaemolyticus strains from the coastal mariculture systems in Guangdong. China. Lett. Appl. Microbiol. 41: 202-207.

Yoder J., M. Hlavsa, G. Craun, V. Hill, V. Roberts, P. Yu, L. Hicks, N. Alexander, R. Calderon, S. Roy and others. 2008. Surveillance for waterborne disease and outbreaks associated with recreational water use and other aquatic facility-associated health events - united states, 2005-2006. MMWR Surveill Summ. 57(9): 1-29. 